\title{
Renal Pelvis and Ureter Cancer Clinical TNM Finding v7
}

National Cancer Institute

\section{Source}

National Cancer Institute. Renal Pelvis and Ureter Cancer Clinical TNM Finding v7. NCI

Thesaurus. Code C89323.

A clinical finding about one or more characteristics of renal pelvis and ureter cancer, following the rules of the TNM AJCC v7 classification system. Primary tumor assessment includes radiographic imaging, usually by intravenous and/or retrograde pyelography. Computerized tomography scanning can be used to assess regional nodes.

Ureteroscopic visualization of the tumor is desirable, and tissue biopsy through the ureteroscope may be performed if feasible. Urine cytology may help determine tumor grade if tissue is not available. (from AJCC 7th Ed.) 